\title{
Isolation and Characterization of a Thermophilic Marine Methanogenic Bacterium, Methanogenium thermophilicum sp. nov. $†$
}

\author{
CHRISTOPHER J. RIVARD AND PAUL H. SMITH \\ Department of Microbiology and Cell Science, University of Florida, Gainesville, Florida 32611
}

\begin{abstract}
A new species of thermophilic marine methanogenic bacteria is described. Cells of this species occurred as irregular cocci, singly or in pairs, and did not possess flagella. Colonies were translucent, beige in color, and circular with entire edges. Either formate or hydrogen and carbon dioxide could serve as a substrate for growth and methane formation, whereas ethanol, methanol, acetate, propionate, and pyruvate could not. The temperature for optimum growth was $55^{\circ} \mathrm{C}$, with minimal growth below $37^{\circ} \mathrm{C}$ and an upper temperature limit of $65^{\circ} \mathrm{C}$. The $\mathrm{pH}$ for optimum growth was 7.0. Sodium chloride was required for growth; the concentration for optimum growth was $0.20 \mathrm{M}$. The minimum generation time was $2.5 \mathrm{~h}$. The deoxyribonucleic acid base composition was $59 \mathrm{~mol} \%$ guanine plus cytosine. The name Methanogenium thermophilicum is proposed for this organism. The type strain is CR-1 (= ATCC 33837 = DSM 2373).
\end{abstract}

The exploration of various ecological niches has resulted in the isolation and characterization of various strains of methanogenic bacteria (see Balch et al. [1] for the most recent review). Of these ecological niches, the high-temperature marine environment has not been extensively explored due to its limited occurrence. One such high-temperature marine environment is available and was explored in this study: the sediment underlying the high-temperature effluent from coastal nuclear power plants. Coastal nuclear power plants use seawater as a coolant. In this study, this high-temperature marine environment was examined for the presence of methanogenic bacteria.

The isolation of a thermophilic marine methanogenic bacterium, aside from being of basic scientific importance, may also have a practical significance in the terminal dissimilation of marine organic matter in a thermophilic digestion system.

\section{MATERIALS AND METHODS}

Sampling procedure. Sediment samples were collected by means of a 3.5 by $55-\mathrm{cm}$ clear Plexiglas tube which was open at both ends. The tube was inserted into the sediment to the desired depth, plugged at the top with a no. 7 rubber stopper, and recovered. The sediment core was then gently pushed out of the tube with a plunger. Subcores were removed with a no. 6 brass cork borer and immediately transferred to pri-

† Journal article no. 3576 of the Florida Agricultural Experiment Station. mary enrichment medium. After transfer to the sterile primary enrichment medium contained in $60-\mathrm{ml}$ serum bottles, the bottles were stoppered and crimped. On arrival at the laboratory, the enrichments were flushed and pressurized to $170 \mathrm{kPa}$ with sterile oxygen-free $\mathrm{H}_{2}-\mathrm{CO}_{2}(80-20 \%)$ gas. The enrichments were incubated at $55^{\circ} \mathrm{C}$. The headspace was analyzed for methane after 1 and 2 weeks of incubation. Enrichments positive for methane formation were diluted serially to a final dilution of $10^{10}$. Agar roll tubes were prepared from each 10-fold dilution. Dilution blanks and agar roll tubes contained the same primary enrichment medium with or without $2 \%$ added agar. Isolated colonies were selected from the highest dilution showing methane formation after 1 week of incubation. Selected colonies were again diluted serially, and roll tubes were prepared from each dilution. This procedure was repeated until all colonies appeared similar, and a pure culture was determined by various criteria.

Media. Primary sediment enrichments were cultivated in $60-\mathrm{ml}$ serum bottles containing sterile reduced growth medium with an $\mathrm{H}_{2}-\mathrm{CO}_{2}$ gas phase. The medium was prepared by a modification of the Hungate technique (6) as described by Bryant and Robinson (3) and as revised by Balch and Wolfe (2).

The primary enrichment medium utilized was that described by Romesser et al. (10). It consisted of the following constituents in a mixture of $30 \%$ distilled water and $70 \%$ aged seawater at the indicated final concentration (wt/vol) in percent: 0.05 ammonium acetate, 0.1 sodium formate, 0.2 Trypticase (BBL Microbiology Systems, Cockeysville, Md.), 0.1 yeast extract (Difco Laboratories, Detroit, Mich.), 0.1 sodium carbonate, 0.05 cysteine hydrochloride, 0.05 sodium sulfide, and 0.0001 resazurin. In addition, three trace solutions ( $1 \%$ final concentration) were added: a trace vitamin solution (modified to include $10 \mathrm{mg}$ of 


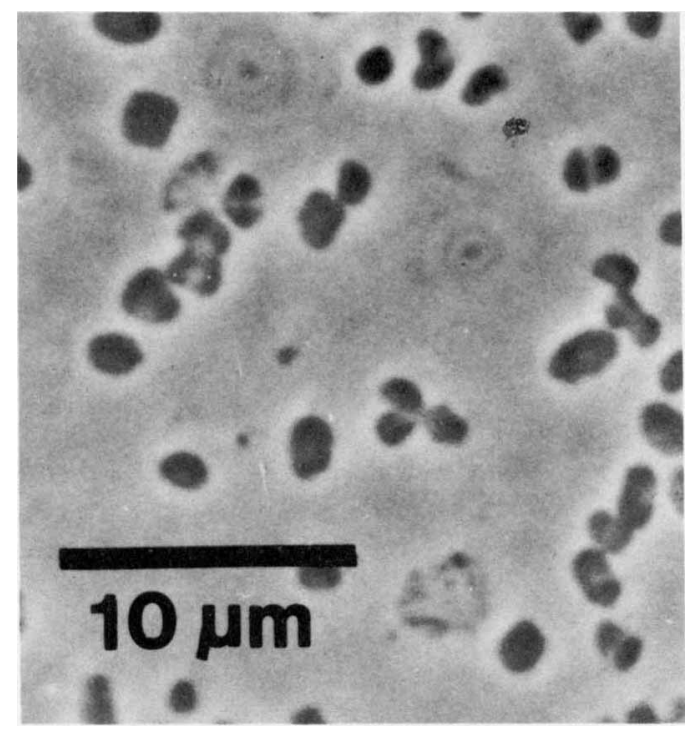

FIG. 1. Phase-contrast photomicrographs of living cells of $M$. thermophilicum $(\times 1,000)$.

sodium 2-mercaptoethanesulfonic acid [CoM] in the stock solution), a trace mineral solution, and a volatile fatty acid solution (isobutyric, 2-methylbutyric, isovaleric, and valeric acids, each at a final concentration of $0.05 \%$ [vol/vol]) (13). The final $\mathrm{pH}$ was adjusted to 7.1 with $2.0 \mathrm{M}$ KOH before autoclaving.

Constituents of the primary enrichment medium and an artificial seawater solution (to replace aged seawater) were analyzed for their requirement for growth in an attempt to derive a defined growth medium. The final growth medium developed and used throughout these studies is referred to as MTSM (Methanogenium thermophilicum standard medium). The MTSM contained the following constituents in final percentages (wt/vol) in distilled water: $0.4 \mathrm{MgCl}_{2} \cdot 6 \mathrm{H}_{2} \mathrm{O}, 0.0075$ $\mathrm{CaCl}_{2} \cdot 2 \mathrm{H}_{2} \mathrm{O}, 1.17 \mathrm{NaCl}, 0.2$ yeast extract, 0.6 Trypticase, 0.0001 resazurin, $0.4 \mathrm{NaHCO}_{3}, 0.014 \mathrm{~K}_{2} \mathrm{HPO}_{4}$, $0.014 \mathrm{KH}_{2} \mathrm{PO}_{4}, 0.05$ cysteine hydrochloride, and $1 \%$ (vol/vol) trace vitamin solution. The $\mathrm{pH}$ was adjusted to 7.1 with $2.0 \mathrm{M} \mathrm{KOH}$ after the addition of cysteine hydrochloride. After autoclaving and pressurization to $170 \mathrm{kPa}$ with an $80-20 \% \mathrm{H}_{2}-\mathrm{CO}_{2}$ gas mixture, the $\mathrm{pH}$ was approximately 7.0.

Standard assay conditions. All culture conditions were the same unless otherwise stated. Three 18 - by $150-\mathrm{mm}$ stoppered and crimped serum tubes containing $9.5 \mathrm{ml}$ of anaerobic sterile growth medium were inoculated with $0.5 \mathrm{ml}$ from a log-phase culture grown at $55^{\circ} \mathrm{C}$ in $\mathrm{MTSM}$ with a $170 \mathrm{kPa} \mathrm{H}_{2}-\mathrm{CO}_{2}$ gas phase to serve as growth substrate. Inoculated tubes were then pressurized to $170 \mathrm{kPa}$ with sterile oxygen-free $80-20 \%$ $\mathrm{H}_{2}-\mathrm{CO}_{2}$ gas. Tubes were incubated at $55^{\circ} \mathrm{C}$ with medium inversion speed on a Fisher roto-rack (model 343). Uninoculated controls were carried under identical conditions, except that $0.5 \mathrm{ml}$ of sterile MTSM was added in place of the log-phase growth culture. Experimental tubes were read every $4 \mathrm{~h}$ on a Perkin-Elmer (model Coleman 44) spectrophotometer at $610 \mathrm{~nm}$.
Every $4 \mathrm{~h}$, the $170-\mathrm{kPa} \mathrm{H}_{2}-\mathrm{CO}_{2}$ atmosphere was reestablished.

Treatment and analysis of gases. Methane, hydrogen, and carbon dioxide were analyzed by means of a Loenco model 15A gas chromatograph. The gas chromatograph was equipped with a Porpack $Q$ column $(1.8 \mathrm{~m}$ by $4 \mathrm{~mm})$ connected to a thermal conductivity detector. Nitrogen was used as the carrier gas. The temperature in the column and detector was maintained at $27^{\circ} \mathrm{C}$. Methane concentrations were calibrated by comparison with standards of ultra-high-purity methane (Matheson Scientific, Inc., Rutherford, N.J.). The $\mathrm{H}_{2}-\mathrm{CO}_{2}$ and other gases were sterilized by passage through a $2.5-\mathrm{ml}$ syringe barrel packed with sterile cotton. The gases were made oxygen-free by passage over hot reduced copper filings.

Photomicrographs. Photomicrographs of cells were made with a Carl Zeiss universal microscope with a Leica camera attachment. Wet mounts were prepared on slides which had been previously coated with $0.85 \%$ centrifuged Ionagar no. 2 (Colab) and air dried.

Electron microscopy. Mid- to late-log-phase cells were prepared by primary fixation in $2 \%$ glutaraldehyde solution (final concentration) supplemented with $2 \%$ (wt/vol) $\mathrm{NaCl}$. The primary fixation was carried out at $55^{\circ} \mathrm{C}$ to avoid possible distortions caused by fixation at suboptimal temperatures. After $0.5 \mathrm{~h}$ of fixation with glutaraldehyde, an osmic acid solution was added to a final concentration of $2 \%$, and fixation was carried out for 1 additional $h$ at room temperature. The cells were then centrifuged and washed three times with $0.2 \%$ cacodylate buffer solution ( $\mathrm{pH} 7.2$ ) supplemented with $2 \% \mathrm{NaCl}$. After the third wash, the cell pellet was placed into $2 \%$ agar. After solidifying, the agar was cut into small cubes. The agar cubes were then dehydrated in ethanol and embedded in Spurr's low viscosity medium (12). Thin sections were obtained with an LKB Ultratome III ultramicrotome, poststained with saturated uranyl acetate, washed, and followed with lead citrate (9). Electron micrographs were taken with a Hitachi HU-11E electron microscope. Magnifications were calibrated with a line grating replica (Polaron Equipment Ltd.; 2,160 lines per $\mathrm{mm}$ ).

DNA isolation and analysis of base ratio. Cells were lysed with $5 \%$ (vol/vol) Triton X-100, and deoxyribonucleic acid (DNA) was purified by the method of Marmur (7). The buoyant density was determined by centrifugation in a cesium chloride density gradient which included acrylamide polymerization reagents as described by Preston and Boone (8). The procedure was modified to allow detection of minute $(0.5-\mathrm{g})$ amounts of DNA by staining with ethidium bromide and subsequent analysis of fluorescence with an Aminco fluoro-colorimeter at $254 \mathrm{~nm}$ (J. R. Preston, manuscript in preparation). Numerous gels were run with the new isolate and five known DNA standards simultaneously to generate a standard curve. Centrifugation was performed in a Beckman L2 ultracentrifuge. The DNA base ratio (moles percent guanine plus cytosine $[\mathrm{G}+\mathrm{C}]$ ) was calculated by the method of Schildkraut et al. (11).

\section{RESULTS}

A methanogen was isolated from an enrichment culture of sediment taken from the effluent 


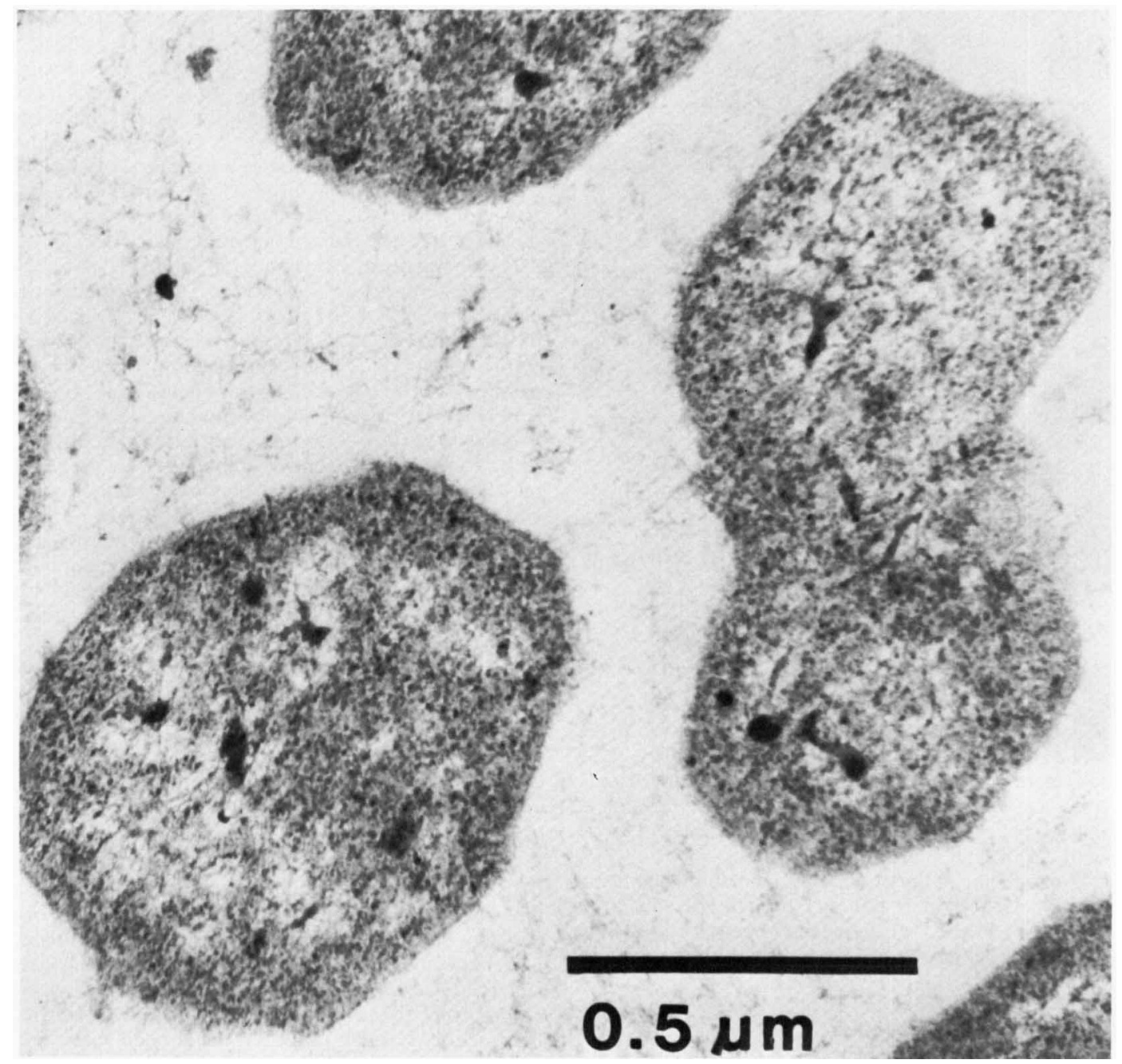

FIG. 2. Thin section of typical cells of $M$. thermophilicum $(\times 49,000)$.

channel of the Crystal River Nuclear Power Plant, Florida Power Company, Crystal River, Fla. The sediment cores were taken along the banks of the effluent channel where the flow of water was reduced. Subcores were taken from the top and middle of each core and placed into a sterile, anaerobic, primary enrichment medium. Methane was detected in two of the five top sediment enrichment cultures after 1 week of incubation at $55^{\circ} \mathrm{C}$. The presence of a pure culture was determined by various criteria, such as identical colony morphology in roll tubes, similar cellular morphology in wet-mount preparations, and fluorescence of all cells and colonies on exposure to $420-\mathrm{nm}$ light. Fluorescence upon excitation with $420-\mathrm{nm}$ light indicates the presence of a coenzyme $F_{420}$ unique to methanogenic bacteria (4).
Single cells of the isolate were observed in the mid-log phase of growth. The cells were gramnegative, irregular cocci which occurred singly or in pairs, as shown in Fig. 1. The average diameter was 1.0 to $1.3 \mu \mathrm{m}$. Neither motility (wet mounts) nor flagella (electron micrographs) was observed. Thin sections examined by electron microscopy revealed several internal structures (Fig. 2 to 4 ). In the majority of cells examined, a dense, fibrous material was present. This fibrous material, located throughout the cell (Fig. 3), was thought to be condensed DNA. Variation of fixation times produced little or no observable change in the appearance of this fibrous material. A granular region in the cytoplasm was suggestive of ribosome-rich regions. An occasional cell appeared to contain internal membrane fragments. These membrane 


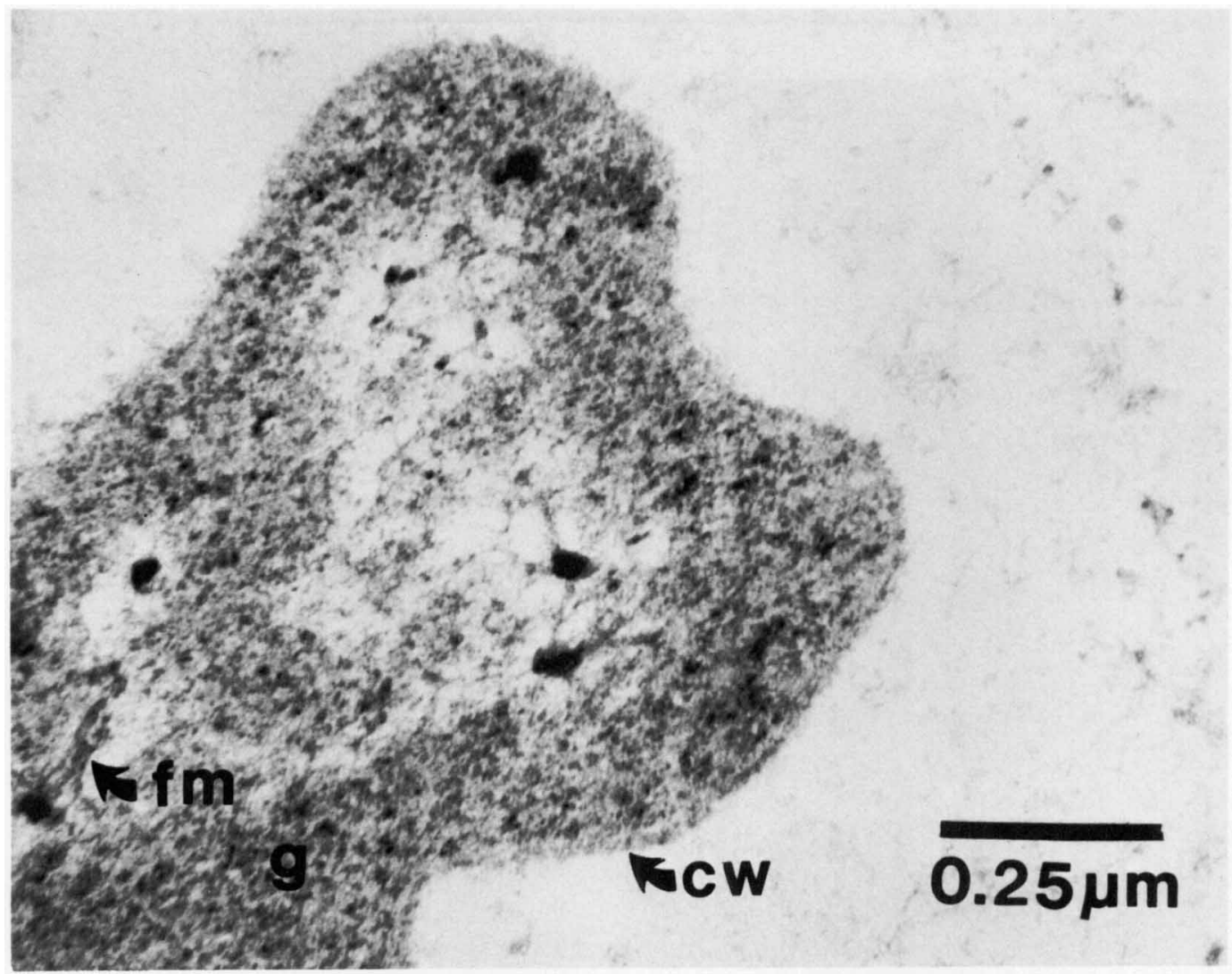

FIG. 3. Thin section of $M$. thermophilicum showing cell wall (cw), granular region $(\mathrm{g})$, and fibrous material (fm) $(\times 63,000)$.

fragments were observed within the cytoplasm and closely adjacent to the cytoplasmic membrane (Fig. 4). The cell walls were observed to dissociate readily from the cytoplasmic membrane in old cultures. These cells remained intact but were surrounded only by the cytoplasmic membrane. The dissociated cell walls did not appear to break down into subunits with the fixation procedures used.

Colonies of the new isolate were approximately 1 to $2 \mathrm{~mm}$ in diameter after 1 week of incubation at $55^{\circ} \mathrm{C}$ in MTSM supplemented with $2.0 \%$ agar. The substrate for growth in roll tubes was a $170-\mathrm{kPa} \mathrm{H} \mathrm{H}_{2}-\mathrm{CO}_{2}$ gas atmosphere. When viewed under a dissecting microscope, colonies were circular with entire edges. They were beige in color and translucent, becoming more opaque with time.

The isolate was found to require Trypticase for growth. Optimum growth occurred with $6.0 \mathrm{~g}$ of added trypticase per liter. This requirement could not be met with $\mathrm{NH}_{4} \mathrm{Cl}$, Proteose no. 3, or tryptone at the same concentration. The trace vitamin solution could be used in place of yeast extract, but growth was only $75 \%$ of that obtained when yeast extract was included. Sodium sulfide was determined not to be required for growth. In fact, reduced growth resulted when sodium sulfide was added to MTSM, as indicated in Table 1.

Various substrates were examined for their use by the new isolate as a source of energy and methane formation (Table 2). Either formate or hydrogen and carbon dioxide were metabolized, whereas ethanol, methanol, acetate, propionate, and pyruvate were not. There was no apparent inhibition of growth in the presence of $1.5 \%$ (final concentration) of each substrate tested when a metabolizable $\mathrm{H}_{2}-\mathrm{CO}_{2}$ atmosphere was present.

The optimum added sodium chloride concentration for growth of the new isolate was determined (Fig. 5). Growth was drastically inhibited at sodium chloride concentrations below 0.075 M. Minimal growth occurred with sodium chloride above $0.70 \mathrm{M}$. The optimum concentration of sodium chloride was $0.20 \mathrm{M}$. Additional sodium ions were available from other sources in the 

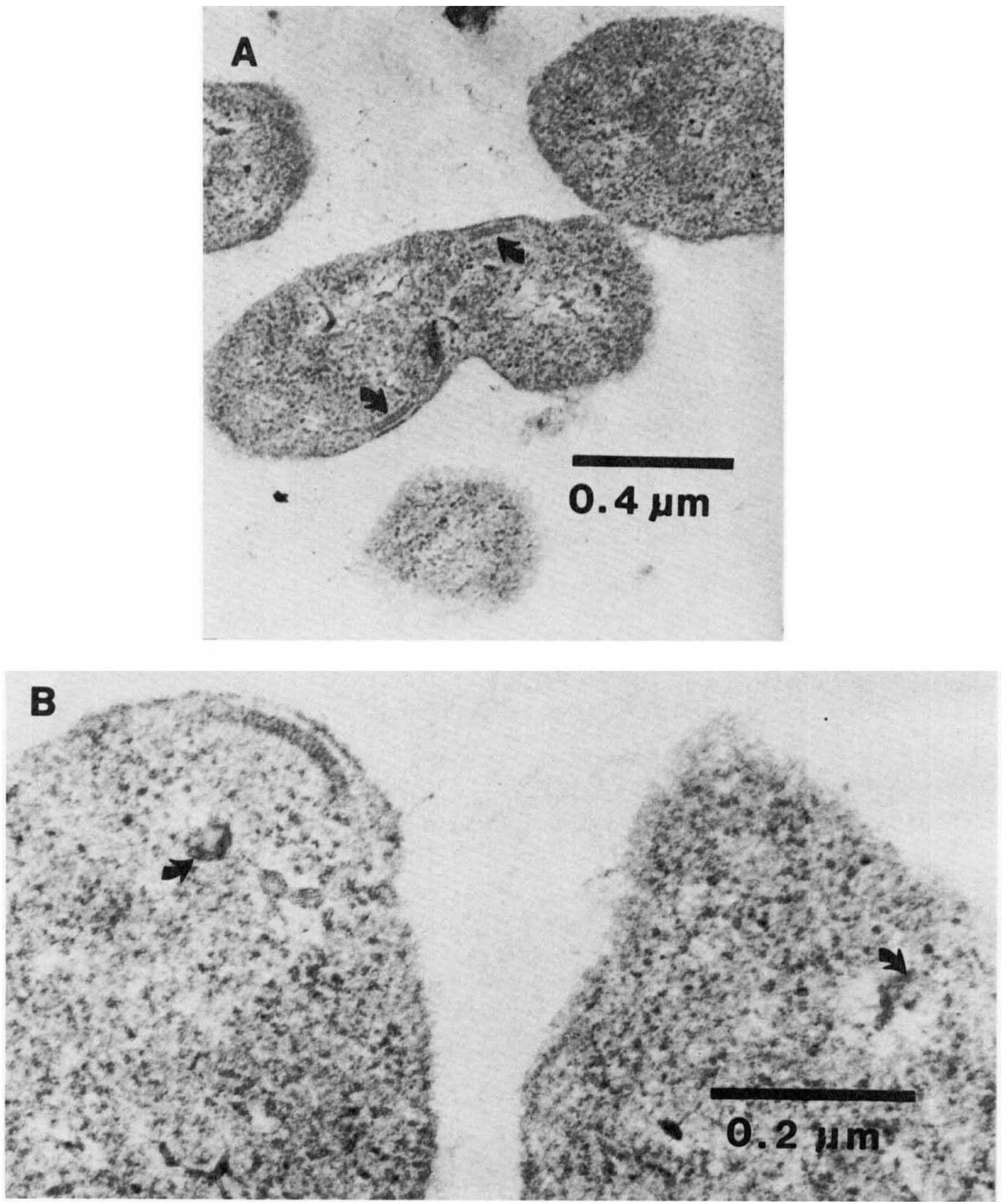

FIG. 4. (A) Stacks of internal membranes adjacent to the plasmal membrane (arrows) $(\times 49,000)$. (B) Two unit membranes fused together found within cytoplasm (arrows) $(\times 124,120)$.

medium $(0.047 \mathrm{M})$, making $0.247 \mathrm{M}$ sodium ion content the optimum for growth. The temperature for optimum growth of the isolate was $55^{\circ} \mathrm{C}$ (Fig. 6). Minimal growth occurred below $37^{\circ} \mathrm{C}$. The upper temperature limit appeared to be $65^{\circ} \mathrm{C}$, at which no significant growth was detected. The $\mathrm{pH}$ for optimum growth (Fig. 7) was found to be 7.0. The lower $\mathrm{pH}$ limit appeared to be approximately 6.18 , with an upper $\mathrm{pH}$ limit above 7.82 .

A minimum generation time of $2.5 \mathrm{~h}$ was observed for growth in MTSM.

The $\mathrm{G}+\mathrm{C}$ content of the DNA of the new isolate was $59 \mathrm{~mol} \%$. 
TABLE 1. Effect of sodium sulfide addition on growth of $M$. thermophilicum

\begin{tabular}{|c|c|c|}
\hline $\begin{array}{l}\text { Reducing } \\
\text { equivalents }\end{array}$ & $\begin{array}{l}\text { Concentration } \\
\text { (g/liter of } \\
\text { MTSM) }\end{array}$ & $\begin{array}{l}\text { Maximal } \\
\text { absorbance } \\
\text { at } 610 \mathrm{~nm} \\
\text { after } 22 \mathrm{~h}\end{array}$ \\
\hline $\begin{array}{l}\text { L-Cysteine } \\
\text { hydrochloride }\end{array}$ & 0.50 & 0.110 \\
\hline $\begin{array}{l}\text { L-Cysteine } \\
\text { hydrochloride }\end{array}$ & 0.50 & 0.104 \\
\hline Sodium sulfide & 0.25 & \\
\hline $\begin{array}{l}\text { L-Cysteine } \\
\text { hydrochloride }\end{array}$ & 0.50 & 0.024 \\
\hline Sodium sulfide & 0.50 & \\
\hline
\end{tabular}

\section{DISCUSSION}

We propose that this new thermophilic marine methanogenic bacterium be placed in the family Methanomicrobiaceae (1) in the genus Methanogenium. The microbe belongs in this genus because its cells are gram-negative, irregular coccoids which occur singly or in pairs, it is sensitive to $1 \%$ sodium dodecyl sulfate, its cell walls become disassociated in older cultures, and it possesses internal membrane components. It also resembles the members of the genus in that it has a high $\mathrm{G}+\mathrm{C}$ base ratio, it utilizes only formate or hydrogen and carbon dioxide as growth substrates and for methane formation, and it has a requirement for sodium chloride.

The new isolate is similar to Methanogenium cariaci in its optimum $\mathrm{pH}$ for growth and to Methanogenium marisnigri in its $\mathrm{G}+\mathrm{C}$ base ratio and its Trypticase requirement. It differs

TABLE 2. Effect of various substrates on methane production by $M$. thermophilicum

\begin{tabular}{llc}
\hline \multicolumn{1}{c}{ Substrate added } \\
& Atmosphere & $\begin{array}{c}\text { Methane } \\
\text { produced }\end{array}$ \\
\hline None & $\mathrm{H}_{2}-\mathrm{CO}_{2}$ & 0.193 \\
None & $\mathrm{CO}_{2}$ & 0.000 \\
Ethanol & $\mathrm{H}_{2}-\mathrm{CO}_{2}$ & 0.191 \\
Ethanol & $\mathrm{CO}_{2}$ & 0.000 \\
Methanol & $\mathrm{H}_{2}-\mathrm{CO}_{2}$ & 0.192 \\
Methanol & $\mathrm{CO}_{2}$ & 0.000 \\
Sodium formate & $\mathrm{H}_{2}-\mathrm{CO}_{2}$ & 1.129 \\
Sodium formate & $\mathrm{CO}_{2}$ & 0.925 \\
Sodium acetate & $\mathrm{H}_{2}-\mathrm{CO}_{2}$ & 0.190 \\
Sodium acetate & $\mathrm{CO}_{2}$ & 0.000 \\
Sodium propionate & $\mathrm{H}_{2}-\mathrm{CO}_{2}$ & 0.191 \\
Sodium propionate & $\mathrm{CO}_{2}$ & 0.000 \\
Sodium pyruvate & $\mathrm{H}_{2}-\mathrm{CO}_{2}$ & 0.193 \\
Sodium pyruvate & $\mathrm{CO}_{2}$ & 0.000 \\
\hline
\end{tabular}

${ }^{a}$ All substrates were added to $1.5 \%$ final concentration.

${ }^{b}$ Pressurized to $170 \mathrm{kPa}$.

${ }^{c}$ Nanomoles of methane produced after 2 weeks.

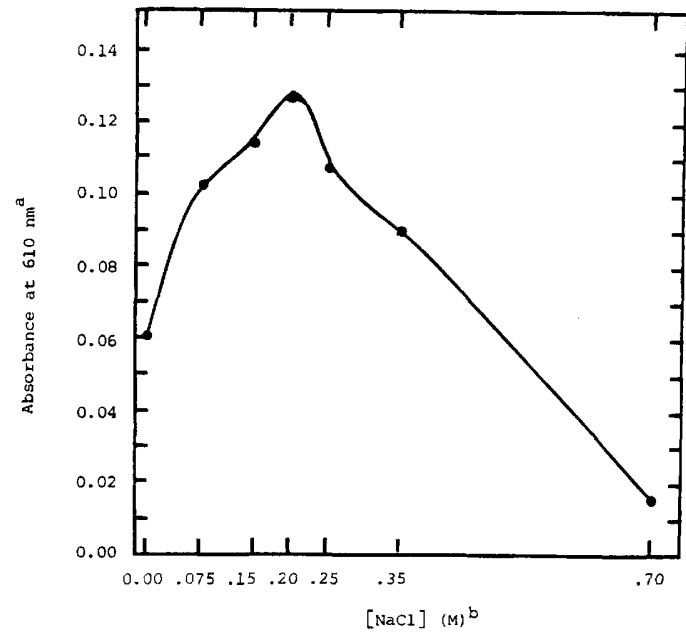

FIG. 5. Effect of sodium chloride concentration on the growth of $M$. thermophilicum. ${ }^{a}$, Maximal absorbance at $610 \mathrm{~nm}$ after $20 \mathrm{~h} .{ }^{\mathrm{b}}$, Molar sodium chloride concentrations do not reflect sodium ions available from other components in the medium.

from $M$. cariaci and $M$. marisnigri in its optimum growth temperature $\left(55^{\circ} \mathrm{C}\right)$ and by its lack of flagella. (Although $M$. cariaci and M. marisnigri possess flagella, the flagella appear to be nonfunctional.)

Recent immunological fingerprint data (E. C. deMacario, personal communication) obtained by the indirect immunofluorescence technique (5) show the new isolate to react only with $M$. cariaci, M. marisnigri, and Methanomicrobium mobile.

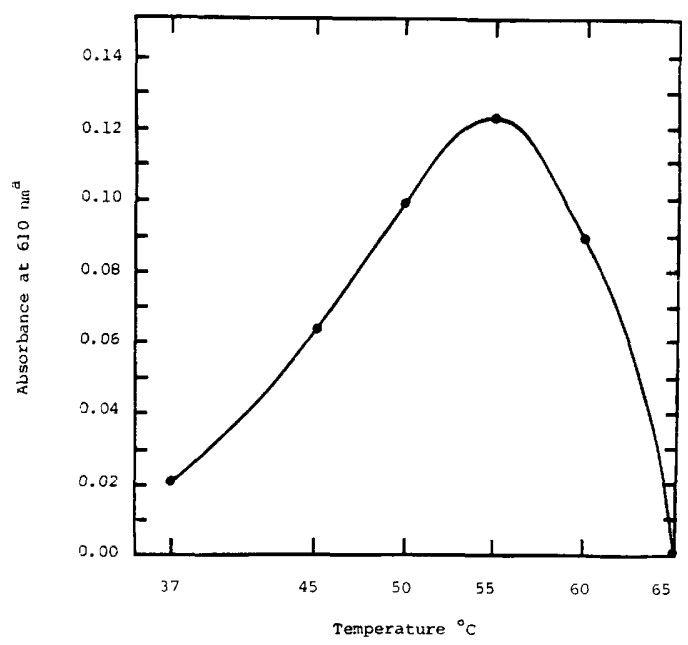

FIG. 6. Effect of temperature on growth of $M$. thermophilicum. $^{\text {a }}$, Maximal absorbance at $610 \mathrm{~nm}$ after $19 \mathrm{~h}$. 


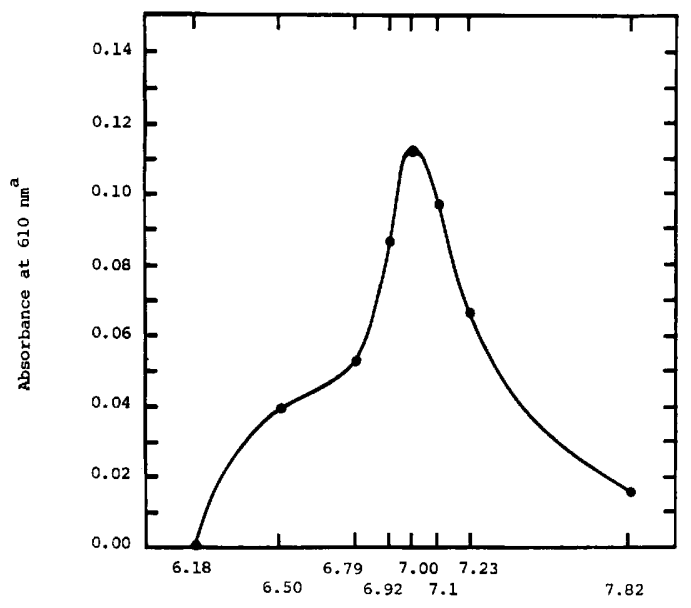

$\mathrm{pH}$

FIG. 7. Effect of pH on growth of $M$. thermophilicum. ${ }^{\mathrm{a}}$, Maximal absorbance at $610 \mathrm{~nm}$ after $20 \mathrm{~h}$.

Therefore, we propose that our isolate be accorded species status, for which we propose the name Methanogenium thermophilicum sp. nov. (ther'mo'phil' $\cdot$-cum; Gr. n. therme, heat; Gr. adj. philicum, loving; M.L. adj. thermophilicum, heat loving.)

Cells are gram-negative, irregular cocci which occur singly or in pairs, with an average diameter of 1.0 to $1.3 \mu \mathrm{m}$; spores are not formed. Electron micrographs reveal occasional internal membrane components.

Colonies in agar tubes are beige and circular with entire edges.

Either formate or hydrogen and carbon dioxide can serve as a growth substrate. Neither growth nor methane production was detected within 2 weeks when the $\mathrm{H}$ electron donor was replaced by ethanol, methanol, acetate, propionate, or pyruvate.

The organism requires Trypticase and a trace vitamin solution.

The temperature for optimum growth is $55^{\circ} \mathrm{C}$.

The $\mathrm{pH}$ for optimum growth is 7.0.

The sodium ion concentration for optimum growth is $0.25 \mathrm{M}$.

The DNA base composition is $59 \mathrm{~mol} \% \mathrm{G}+\mathrm{C}$.

Isolated from sediment underlying the hightemperature effluent channel of the Crystal River Nuclear Power Plant, Florida Power Company, Crystal River, Fla.

Type strain: CR-1 (= ATCC 33837 = DSM
2373). The description of the type strain is the same as that given above for the species.

\section{ACKNOWLEDGMENTS}

This paper reports results from a project that contributes to a cooperative program between the Institute of Food and Agricultural Sciences of the University of Florida and the Gas Research Institute, entitled "Methane from Biomass and Waste.'

We thank the Florida Power Company for authorizing the sampling at the Crystal River Nuclear Plant. We thank James R. Paterek for technical assistance.

\section{REPRINT REQUESTS}

Address reprint requests to: Dr. Christopher J. Rivard, Department of Microbiology and Cell Science, University of Florida, Gainesville, FL 32611.

\section{LITERATURE CITED}

1. Balch, W. E., G. E. Fox, L. J. Magrum, C. R. Woese, and R. S. Wolfe. 1979. Methanogens: reevaluation of a unique biological group. Microbiol. Rev. 43:260-296.

2. Balch, W. E., and R. S. Wolfe. 1976. New approach to the cultivation of methanogenic bacteria: 2-mercaptoethanesulfonic acid (HS-CoM)-dependent growth of Methanobacterium ruminatium in a pressurized atmosphere. Appl. Environ. Microbiol. 32:781-791.

3. Bryant, M. P., and I. M. Robinson. 1961. An improved non-selective culture medium for ruminal bacteria and its use in determining diurnal variation in number of bacteria in the rumen. J. Dairy Sci. 44:1446-1456.

4. Cheeseman, P., A. Toms-Wood, and R. S. Wolfe. 1972. Isolation and properties of a fluorescent compound, factor $_{\mathbf{4 2 0}}$, from Methanobacterium strain M.o.H. J. Bacteriol. 112:527-531.

5. deMacario, E. C., M. J. Wolin, and A. J. L. Macario. 1982. Antibody analysis of relationships among methanogenic bacteria. J. Bacteriol. 149:316-319.

6. Hungate, R. E. 1950 . The anaerobic mesophilic cellulytic bacteria. Bacteriol. Rev. 14:1-49.

7. Marmur, J. 1961. A procedure for the isolation of deoxyribonucleic acid from microorganisms. J. Mol. Biol. 3:208218.

8. Preston, J. R., and D. R. Boone. 1973. Analytical determination of the buoyant density of DNA in acrylamide gels after preparative $\mathrm{CsCl}$ gradient centrifugation. FEBS Lett. 37:321-324.

9. Reynolds, E. S. 1963 . The use of lead citrate at high $\mathrm{pH}$ as an electron opaque stain in electron microscopy. J. Cell Biol. 17:208-212.

10. Romesser, J. A., R. S. Wolfe, F. Mayer, E. Spiess, and A. Walther-Mauruschat. 1979. Methanogenium, a new genus of marine methanogenic bacteria, and characterization of Methanogenium cariaci sp. nov, and Methanogenium marisnegri sp. nov. Arch. Microbiol. 121:147-153.

11. Schildkraut, C. L., J. Marmur, and P. Doty. 1962. Determination of the base composition of deoxyribonucleic acid from its buoyant density in $\mathrm{CsCl}$. J. Mol. Biol. 4:430 443.

12. Spurr, A. R. 1969. A low viscosity epoxy resin embedding medium for electron microscopy. J. Ultrastruct. Res. 26:31-43.

13. Wolin, A. E., M. J. Wolin, and R. S. Wolfe. 1963. Formation of methane by bacterial extracts. J. Biol. Chem. 238:2882-2886. 